\title{
Pengaturan Delik Pidana Terkait Tindakan Bulying Bagi Anak di Bawah Umur
}

\author{
Dewa Krisna Prasada ${ }^{1}$
}

${ }^{1}$ Majalah Hindu Times, Denpasar-Bali, E-mail : $\underline{\text { hindutimesbali@gmail.com }}$

\begin{tabular}{l}
\hline Info Artikel \\
\hline Masuk: 17 Juni 2019 \\
Diterima: 12 Juli 2019 \\
Terbit: 21 Juli 2019 \\
Keyword: \\
Bullying; Perpetrator; \\
Sanction. \\
\\
Kata kunci: \\
Bullying; Pelaku; Sanksi. \\
Corresponding Author: \\
Dewa Krisna Prasada, \\
E-mail: \\
hindutimesbali@gmail.com \\
DOI : \\
10.24843/AC.2019.v04.02.p.01
\end{tabular}

\section{Pendahuluan}

Bullying merupakan tindakan mengintimidasi satu orang atau lebih, dimana pelaku bullying menganggap target sasarannyadi bawah kemampuannya. Pelaku cenderung berusaha memaksa korban melangsungkan suatu perbuatan yang di luar kapasitas dengan tujuan mecelakakan korban, baik dengan cara menghina atau dengan tekanan jasmani. Praktik bulying sering terjadi dikalangan anak-anak dibawah umur khusunya dilingkungan sekolah mereka. Praktik bullying sering dilakukan akibat dari Televisi

\begin{abstract}
Bullying has lately become a top issue, more commonly to school children, and the perpetrators are also underaged school ingsters. The aims of the study are to review category of bullying from criminal law and to analyze legal sanction for the perpetrator as well. This study administers normative research method by law and case approaches. The result of the study shows that every child has right to live and develop as regulated in Article 4 of Law no. 35 Year 2014 on juvenile protection. Bullying, therefore, cannot be justified. Bullying is categorized as criminal action as regulated in Article 71 Section (1) of Law No. 11 Year 2012 on juvenile court system. Perpetrator of bullying is sanctioned primary punishments which include criminal warning, conditional punishment, work training, coaching in institution, and imprisonment.

\begin{tabular}{l}
\hline Abstrak \\
\hline Bullying akhir-akhir ini menjadi isu hangat umumnya \\
dikalangan anak-anak sekolah dan pelakunya pun anak-anak \\
sekolah yang di bawah umur. Tujuan studi ini untuk mengkaji \\
kategori tindakan bullying dari aspek hukum pidana dan untuk \\
menganalisis sanksi hukum bagi pelaku tindakan bullying. \\
Riset ini menggunakan metode penelitian normatif dengan \\
pendekatan perundang-undangan dan pendekatan kasus. Hasil \\
studi menunjukkan bahwa setiap anak mempunyai hak untuk \\
hidup dan berkembang sebagaimana diatur dalam Pasal 4 \\
Undang-undang Nomor 35 Tahun 2014 Tentang Perlindungan \\
Anak, karenannya tindakan bullying tidak dapat di benarkan. \\
Tindakan bullying ini termasuk dalam kategori tindakan pidana \\
seperti yang di tentukan dalam Pasal 71 ayat (1) Undang- \\
undang Nomor 11 Tahun 2012 Tentang Sistem Peradilan Anak. \\
Pelaku bullying dikenakan sanksi pidana pokok yang meliputi \\
pidana peringatan, pidana dengan syarat, pelatihan kerja, \\
pembinaan dalam lembaga, dan penjara.
\end{tabular}
\end{abstract}


yang kurang mendidik dan juga faktor media sosial yang kurang dibatasi oleh orang tua anak tersebut.

Akhir-akhir ini intensitas terhadap tindakan bullying sering terjadi dilingkungan sekolah, adanya berbagai tindakan kekerasan atau bullying terhadap anak dibawah umur mengakibatkan anak mengalami gangguan perkembangan baik secara fisik maupun mental psikologi mereka. Pelaku bullying saat ini lebih cenderung dilakukan oleh anak-anak dibawah umur, seperti contohnya peristiwa bullying yang dilakukan seorang siswa SD di Thamrin city, Jakarta Pusat1, selain itu terdapat juga kasus bullying yang dilakukan oleh siswa SMA Don Bosco, Jakarta pada Bulan Agustus $2012^{2}$, dan masih banyak kasus bullying yang terjadi diluar sana yang belum terlihat.

Dari uraian diatas, dapat dilihat kata bullying masih dirasa asing bagi para masyarakat khususnya orangtua dan disaat bersamaan para orangtua atau masyarakatlebih memilih untuk mengganggap bahwa tindakan bullying tersebut hanya sebuah kenakalan anak yang tidak serius.

Sejatinya seorang anak merupakan darah daging para orangtua untuk melanjutkan dinasti keluarga mereka. Ketentuan dalam Undang-undang Nomor 35 Tahun 2014 tentang Perlindungan anak, ditentukan bahwa anak yang lahir memiliki hak untuk hidup dan berkembang, seorang anak juga harus dilindungi dari kekerasan baik secara verbal ataupun fisik, hal ini sesuai denganaturan pokok negara yaitu Undang-undang Negara Republik Indonesia Tahun 1945. Seorang buah hati merupakan bibit yang memiliki potensi sebagai generasi selanjutnya yang mewairisi tujuan bangsa negara, seorang anak memiliki andil dengan sifat-sifat yang istimewa untuk menjaga keseimbangan negara dimasa depan. Seluruh anak yang hidup berhak mendapatkan peluang yang seluas-luasnya untuk bertumbuh secara ideal dan baik dari segi akademis ataupun non akademis agar di masa yang akan datang mereka siap untuk mengemban tugas-tugas yang diwariskan oleh para leluhur bangsa. Salah satu cara agar hal tersebut terlaksana yaitu dengan cara mewujudkan kemakmuran di lingkuangn anak yang sedang berkembang harus menghapus hal-hal yang berbau diskriminasi ${ }^{3}$. Bedasarkan uraian diatas, terdapat permasalahan yang serius untuk membahasa mengenai tindakan bullying tersebut seperti apakah tindakanBullying merupakan tindakan pidana ataukah hanya kenakalan anak dibawah umur? dan bagaimana tindakan hukum terhadap pelaku bullying yang merupakan anak dibawah umur?

Tujuan dari dilakukannya penelitian ini tidak lepas dari fenomena-fenomena yang terjadi mengenai tindakan bullying yang dilakukan oleh anak di bawah umur dan korbannya sudah pasti anak yang memiliki umur sebaya dengan pelaku atau lebih kecil dari pelaku. Selain itu tindakan bullying ini masih dianggap tidak serius oleh masyarakat umu khususnya orang tua, oleh karena itu agar lebih jelasnya penelitian ini memiliki tujuan yaitu mengkaji dari segi hukum apakah tindakan bullying merupakan suatu tindakan kenakalan biasa atau suatu tindak pidana yang membuat

1 Andry Haryanto, Pelajar Pelaku Bullying Dikeluarkan Dari Sekolah, https://www.liputan6.com/news/read/3026316/pelajar-pelaku-bullying-di-thamrin-citydikeluarkan-dari-sekolah. Diakses pada tanggal 29 April 2019.

2 Arbi Sumandoyo, Polisi Tahan 7 Siswa Pelaku Bullying di SMA Don Bosco, https://www.merdeka.com/jakarta/polisi-tahan-7-siswa-pelaku-bullying-sma-donbosco.html. Diakses pada tanggal 29 April 2019.

32Djamil, M. Nasir , 2013, Anak Bukan Untuk Dihukum, Sinar Grafika, Jakarta, hlm. 8. 
anak harus berperkara dengan hukum dan sanksi apa saja yang dapat diberikan kepada seorang pelaku bullying yang di bawah umur.

Seiring berjalannya waktu, dalam era globalisasi digital ini, tindakan bullying tidak hanya dilakukan disekolah ataupun di lingkungan sosial anak, namun juga dilakukan di dunia maya atau bahasa umum saat ini media sosial. Tindakan bullying yang dilakukan dalam ruang lingkup media sosial dikatakan sebagai cyberbullying. Seperti yang dijelaskan oleh Subaidah Rata Juita dalam kajian ilmiahnya bahwa Tindakan cyberbullying ini masuk dalam kategori tindakan pidana dan pelaku akan dikenakan sanksi pidana penjara selama 3 tahun 6 bulan atau denda paling banyak Rp. 72.000.000 (tujuh puluh dua juta) 4 . Tindakan bullying ini merupakan suatu tindakan yang sangat amat serius dan harus dikaji demi menyelamatkan masa depan anak. Trini Handayani menjelaskan tindakan bullying di negara-negara maju sudah pada tingkat yang sangat memprihatinkan karena berdampak dengan terjadinya kasus bunuh diri dari korban bullying 5 . Oleh karena itu diharapkan kedepannya para orang tua dan penegak hukum lebih memperhatikan kejadian bullying ini lebih serius dan memberikan sanksi yang sesuai kepada anak pelaku tindakan bullying. Melista Aulia Nurdina berpendapat bahwa sebaiknya para aparat penegak hukum perlu memahami lebih dalam tentang perkara bullying dan sanksi pidana apa saja yang tepat dijatuhkan kepada pelaku dimana pelaku ini merupakan anak di bawah umur. Selain itu para aparat penegak hukum perlu melakukan sosialisasi hukum terhadap masyarakat khususnya para orang tua agar para orang tua lebih memahami mengenai dampak dari bullying dan diharapkan kedepannya agar kasus bullying ini bisa di minimalisir6.

\section{Metode Penelitian}

Bentuk kajian ilmiah dalammelakuakan studi hukum ini yaitu jenis kajian normatif. Pada hakikatnya kajian hukum normatif mengkaji suatu konsep hukum yang digunakan sebagai suatu aturan atau kaidah yang saat ini berlaku di kalangan masyarakat, dan kaidah-kaidah ini dijadikan patokan oleh masyarakat dalam berprilkau secara umum. ${ }^{7}$

\section{Hasil dan Pembahasan}

\subsection{Observasi Bullying Dari Prespektif Hukum}

Bullying sewajarnya lebih banyak ditemui dalam lingkungan sekolah dan dilakukan oleh para remaja atau anak dibawah umur. Istilah bullying ini sangatlah baru dalam kosa kata bahasa Indonesia. Secara sederhana Sejiwa Diena Haryana memberikan

\footnotetext{
${ }^{4}$ Juita, S. R., Sihotang, A. P., \& Ariyono, A. (2019). Cyber Bullying Pada Anak Dalam Perspektif Politik Hukum Pidana: Kajian Teoretis Tentang Undang-Undang No. 11 Tahun 2008 Tentang Informasi Dan Transaksi Elektronik Sebagaimana Diubah Dengan Undang-Undang No. 19 Tahun 2016. Jurnal Dinamika Sosial Budaya, 20(2), 134.

${ }^{5}$ Handayani, T. (2018). Perlindungan Dan Penegakan Hukum Terhadap Kasus Kekerasan Seksual Pada Anak. Jurnal Hukum Mimbar Justitia, 2(2), 836.

${ }^{6}$ Nurdina, M. A., \& Tri Andrisman, F. (2018). Penegakan Hukum Pidana Terhadap Pelaku Tindakan Penindasan Atau Bullying Di Sekolah Dasar. Jurnal Poenale, 6(2), 1.

${ }^{7}$ Ishaaq, 2017, Metode Penelitian Hukum Penulisan Skripsi, Tesis, Serta Desertasi, Alfabeta, Bandung, hlm. 66.
} 
definisi bullying sebagai penggunaan otoritas atau kekuatan untuk melukai satu insan atau kaum sehingga target bullying merasa teraniaya, mengalami tekanan jiwa, dan tidak berkuasa dalam situasai kehidupannya. Bentuk bullying terbagi menjadi tiga yaitu8:

Tabel 1.1. Bentuk Bullying Terhadap Anak

\begin{tabular}{cccc}
\hline No. & Fisik & Verbal & Psikologis \\
\hline 1. & Memukul & Memaki & Mengintimidasi \\
2. & Menampar & Menggosip & Mengucilkan \\
3. & Memalak & Mengejek & Mengabaikan \\
& & & Mendeskriminasi \\
\hline
\end{tabular}

Bullying sebagai salah satu dampak baru untuk mengetahui lingkungan dimana berlangsungnya suatu penyalahan otoritas/kekuatan yang diperbuat oleh satu orang atau kawanan anak-anak dimana kejadian atau perlakuan bullying ini kerap terjadi dihampir setiap sekolah dimana perlakuan bullying ini sudah tertanam tradisi dimana kekerasan yang disangka oleh pelaku adalah sah dalam suatu proses pendidikan pembelajaran kepada siswa-siswi sekolah.

Praktek tindakan bullying ini merupakan salah satu contoh dari kenakalan anak yang bersifat berlebihan. Oleh sebab itu terdapat beberapa aspek yang menggerakkan dan memotivasi/impulspribadi anak sehingga merekamelancarkan suatu perbuatan nakal yang berlebihan atau bisa dikatakan bullying, yang dimana nantinya akan menimbulkan reaksi dari anak untuk kenakalan yang diperbuatnya. Menurut Romli Atmasasmita ada dua macam impuls/motivasi yaitu Intrinsik dan Ekstrinsik ${ }^{9}$.

Hasrat atau keinginan pada pribadi suatu individu yang tidak perlu dibarengi dengan stimulus dari luar dikategorikan sebagai impuls intrinsik. Begitu pula dengantimbulnya hasrat karena adanya pengruh dari luar dikategorikan sebagai motivasi ekstrinsik. Berikut merupakan ciri-ciri dari impuls intrinsik dan ekstrinsik dilihat dari fenomena bullying, yaitu10:

\footnotetext{
${ }^{8}$ Regina Putri Pratiwi, Hubungan Perilaku Bullying Dengan Kemampuan Interkasi Sosial Siswa Kelas III SDN Minomartani 6 Sleman. Jurnal Fakultas Imu Pendidikan Universitas Negeri Yogyakarta, vol.5 no.2 2016, http://journal.student.uny.ac.id/ojs/index.php/pgsd/article/view/415, diakses tanggal 26 April 2019.

${ }^{9}$ Winna A. A. Senandi dan Tom A. S. Reumi, Penanggulangan Deliquency (Kenakalan Anak dan Remaja), Dampak dan Penanganannya. Jurnal Fakultas Hukum Universitas Cendrawasih, vol.2 no.3 edisi nopember 2018, http://ejournal.uncen.ac.id/index.php/IP/article/ view/659, diakses tanggal 26 April 2019.

${ }^{10}$ Eleanora, F. N. (2019). Kajian Yuridis Penerapan Sanksi Tindakan Terhadap Anak Yang Melakukan Tindak Pidana Menurut Undang-Undang No. 3 Tahun 1997 Tentang Pengadilan Anak. ADIL: Jurnal Hukum, 6(2), 138.
} 
Tabel 1.2. Bentuk Impuls Intrinsik dan Ekstrinsik

\begin{tabular}{ccc}
\hline No. & Intirinsik & Ekstrinsik \\
\hline 1. & Intelektual & Keluarga \\
2. & Umur & Pengajaran di Sekolah \\
3. & Kelamin & Lingkungan sosial anak \\
4. & Kedudukan & Media massa/social \\
& & media \\
\hline
\end{tabular}

Dari penjelasan diatas dilihat bahwa motivasi instrinsik dimana faktor intelegensia memliki faktor yang krusial dimana pendidikan anak yang rendah dan kurang pemahaman dalam melakukan suatu perbuatan bisa menyebabkan terjadinya suatu kefasikanyang diperbuat oleh anak sehingga menimbulkandampak anak yang berperkara dengan hukum, faktor lain juga mempengaruhi tindakan bullying seperti faktor usia dimana usia anak yang masih sangat remaja dan labil menyebabkan anak belum bisa berpikir rasional dengan apa yang dilakukan juga dengan akibat atas perbuatan yang dilakukan.

Motivasi ekstrensik dalam kategori kenakalan anak diatas ada beberapa faktor yang memiliki peran penting dalam penyebab kenakalan anak yaitu faktor keluarga dimana keluarga adalah tempat terdekat dimana anak berkembang dan belajar dari anak balita hingga remaja, keluarga merupakan suatu kelompok yang paling dekat dan pastinya akan mempengaruhi perkembangan anak karena keluarga adalah lingkungan belajar anak untuk pertama kalinya, ketika lingkungan keluarga baik maka anak yang tumbuh dan berkembang didalamnya akan baik juga, namun jika lingkungan keluarga buruk maka yang terjadi terhadap anak akan sebaliknya.

Faktor pendidikan dan sekolah juga merupakan faktor yang tidak kalah pentingnya dengan faktor keluarga dimana sekolah meripakan tempat belajar anak yang kedua, lingkungan sekolah merupakan tempat pendidikan keilmuan bagi anak, jadi lingkungan sekolah juga bertanggung jawab terhadap ilmu apa yang didapatkan anak serta pembentukan karakter anak. Disekolah anak-anak akan melakukan interkasi terhadap teman-temannya, dimana karekater setiap anak itu berbeda, bisa diantara kawan anak-anak tersebut memberikan pengaruh positif atau negative dalam pergaulan misalnya dalam pergaulan yang negative yaitu adanya prakter bullying atau belajar untuk mencuri bahkan sampai belajar berkelahi. Disini peran guru sangatlah penting bagi perkembangan karakter anak sebagai siswa sekolah.

Uraian diatas tercermin di dalam Undang-undang Dasar Negara Republik Indonesia Tahun 1945pada Pasal 28b ayat (2) ditulis bahwa: "Setiap anak berhak atas kelangsungan hidup, tumbuh, dan berkembang serta berhak atas perlindungan dari kekerasan dan diskriminasi". Selain itu dalam Undang-undang nomor 35 Tahun 2014 Tentang perubahan atas Undang-undang Nomor 23 tahun 2002 Tentang Perlindungan anak ditulis pada Pasal 1 angka (2) yaitu "Perlindungan Anak adalah segala kegiatan untuk menjamin dan melindungi Anak dan hak-haknya agar dapat hidup, tumbuh, berkembang, dan berpartisipasi secara optimal sesuai dengan harkat dan martabat kemanusiaan, serta mendapat perlindungan dari kekerasan dan diskriminas". 
Peraturan-peraturan yang di tentukan diatas dilihat bahwa perlindungan terhadap anak itu sangatlah penting. Selain itu fenomena bullying ini sangat berkaitan dengan perlindungan anak dan hak-hak anak untuk berkembang dilingkungan sosialnya, jika terjadi tindakan bullying ini dan tidak adanya tindakan dari pemerintah maka hak-hak anak untuk tumbuh berkembang akan terhambat.

\subsubsection{Teori-teori dalam pemidanaan}

Dalam pembahasan mengenai teori pemidanaan dimana teori pemidanaan dalam literature lazim disebut dengan teori hukum pidana atau strafrecht theorien, teori hukum pidana terhubung langsung dengan pengertian hukum pidana yang bersifat subyektif. Sastrawidjaja dalam Bilher Hutahaean menjelaskan bahwa teori-teori dalam hukum pidana mencari dan menerangkan mengenai dasar dari hak negara dalam menjatuhkan dan menjelankan pidana tersebut, sehingga ada beberapa macam pendapat mengenai teori pemidanaan ini, namun yang banyak itu dapat dikelompokkan ke dalam tiga golongan besar, seperti teori absolute atau teori pembalasan, teori relatif atau tujuan, dan teori gabungan ${ }^{11}$.

Teori absolut atau teori pembalasan (vergeldingstheorien) merupakan pemeberian pidana dilihat dari seseorang yang telah melakukan suatu kejahatan kriminal. Jika dilihat dari sudut pandang teori pembalasan, penderitaan yang diberikan terhadap pelaku harus dibalas dengan penderitaan berupa pidana yang sama sesuai dengan apa yang diperbuatnya. Dalam teori ini pidana yang dijatuhkan terhadap pelaku tidak untuk suatu hal yang praktis, seperti memperbaiki pelaku untuk menjadi pribadi yang lebih baik, namun pidana yang dimaksud yaitu hanya untuk memberikan penderitaan kepada pelaku kejahatan. Ada dua sudut pandang dalam suatu tindakan pembalasan yaitu sudut subjektif yang ditujukan kepada orang yang berbuat salah dan sudut objektif yang ditujukan untuk memenuhi perasaan balas dendam masyarakat ${ }^{12}$.

Utilitariantheory atau lazim disebut dengan teori relatif, memiliki pola kerja mengubah prilaku dari apra pelaku kriminal dari buruk menjadi lebih baik. Menurut teori ini pidana bukan suatu alat untuk melakukan suatu pembalasan dendam kepada pelaku kejahatan, pidana memiliki tujuan yang lebih muliah dari suatu pembalasan. Tujuantujuan kusus dalam teori ini antara lain untuk menentramkan masyarakt yang merasa risau akan terjadinya suatu kejahatan. Tujuan lain yaitu dengan gerakan preventif dalam peristiwa kejahatan. Ada dua bentuk yaitu genarale preventif (umum) dan speciale preventif (khusus) ${ }^{13}$.

Teori pembalasan dan teori relatif bukanlah suatu teori yang bertolak belakang, hal ini terbukti dengan adanya teori gabungan yang memadukan antara teori absolut dengan teori relaitf. Pada dasarnya teori gabungan dalam suatu pembenaran pidana terletak pada kejahatan maupun tujuan pidanannya. Salah satu pengenut teori ini yaitu Karl Binding14. Terdapat tiga golongan dalam teori gabungan yaitu:

\footnotetext{
${ }^{11}$ Hutahaean, B. (2013). Penerapan Sanksi Pidana Bagi Pelaku Tindak Pidana Anak. Jurnal Yudisial, 6(1), 68.

${ }^{12}$ Ibid, hlm, 69.

${ }^{13}$ Ibid.

${ }^{14} \mathrm{Ibid}$, hlm, 70
} 
1. pemidanaan menitik beratkan pada pembalasan yang seimbang dengan perbuatannya dan tidak melibihi standar ketertiban umum.

2. Pemidanaan yang berfokus pada pertahanan, ketertiban umum, dan pemidanaan tidak boleh lebih berat dari perbuatan pidana yang dilakukan oleh pelaku.

3. Berfokus kepada pembalasan dan pertahanan ketertiban masyarakat dalam posisi yang sejajar.

\subsubsection{Penjatuhan Pidana terhadap anak sebelum akil baligh}

Minderjarig merupakan suatu ungkapan yang dipakai dalam KUHP mengenai tuntutan terhadap orang yang belum dewasa atau di bawah 16 (enam belas) tahun. Jika seorang masih belum cukup umur berhadapan di peradilan maka hakim dapat memerintahkan pihak yang bersalah untuk dikembalikan kepada orangtua atau walinya, tanpa dijatuhi pidanan apapun atau anak tersebut diserahkan kepada pemerintah dan peristiwa kejahatannya belum lewat 2 tahun dari sejak pelaku dinyatakan bersalah, hal ini ditegaskan dalam Pasal 45 KUHP.

Dalam hal menjatuhkan pidana terhadap individu yang umurnya diabawah 16 (enam belas) Pasal 47 KUHP mengatur bahwa hakim dapat menjatuhkan pidana maksimum pidana pokok yang dikurangi sepertiga. Jika kejahatan yang diperbuat sampai pada tahap ancaman hukum mati atau seumur hidup, maka hakim cukup memberikan hukum paling lama 15 (lima belas) tahun penjara. Pidana tambahan di dalam KUHP tidak dapat dijatuhkan kepada anak pelaku tindak pidana yang berumur 12 (dua belas) tahun.

Berbeda halnya dengan anak yang berumur dibawah 12 (dua belas) lebih tepatnya anak umur 8 (delapan) tahun, yang melakukan tindakan kriminal belum dapat diadili dalam peradilan anak. Hal ini dipengaruhi faktor sosiologis, psikologis, dan pedagogis ${ }^{15}$. Anak yang belum berumur 8 (delapan) tahun masih dipertanyakan pertaanggungjawabannya dalam perbuatannya. Jika anak tersebut sudah berumur 8 (delapan) tahun atau lebih daapt diajukan dalam peradilan anak. Batas umur yang dapat diadili dalam peradilan anak yaitu maksima berumurl 18 (delapan belas) tahun.

\subsection{Konflik Hukum dan Penanggulangan tindakan Bullying terhadap Anak}

Istilah kenakalan atau Bullying anak-anak dijadikan kategori terhadap anak-anak yang bermasalah sebelum lahirnya aturan negara mengenai perlindungan anak di tahun 2002, kategori bullying/kenakalan anak ini mengacu pada Undang-undang Nomor 3 Tahun 1997 Tentang Pengadilan anak. Setelah diundangkannya Undang-undang Perlindungan Anak tersebut maka istilah kenakalan anak diubah yaitu sebagai seorang anak yang berkonflik di hadapan hukum atau bisa disingkat menjadi $\mathrm{ABH}$ (anak yang berkonflik dengan hukum), dan saat inidalam ketentuan sistem peradilan anak digunakan istilah anak yang berkonflik dengan hukum di dalam ketentuan Pasal 1 ayat (2) undang-undang Nomor 11 Tahun 2012.

Salah satu ciri dari anak yang nakal dalam prespektif pandangan hukum yaitu memiliki ciri anak yang melangsungkan suatu tindak pidana atau melakukan suatu

\footnotetext{
${ }^{15}$ Ibid, hlm, 72.
} 
tindakan yang dilarang dalam aturan negara, hal ini di tegaskan dalam aturan mengenai pengadilan anak yaitu Undang-undang Nomor 3 Tahun 1997 namun selepas adanya perbuhan dari undang-undang pengadilan anak menajadi undang-undang sistem peradilan anak yaitu undang-undang Nomor 11 Tahun 2012 maka definisi anak nakal diubah menjadi konflik anakterhadap hukum. Secara umum memang pengertian anak nakal itu sangat banyak dikarenakan ada hal yang dianggap kenakalan seorang anak sifatnya tidak berbahaya. Namun bagaimana jadinya apabila suatu kenakalan tersebut sampai mengakibatkan hilangnya nyawa seseorang. Hal ini menjadi fokus ketentuan dalam aturan negara mengenai perlindungan dan sistem peradilan anak di Indonesia.

Terdapat 2 (dua) macam unsur kategori mengapa seorang anak dapat dikatakan berhadapan dengan hukum, unsur-unsur tersebut antaralain:

1. Unsur Offense dimana unsur ini merupakan prespektif seorang anak mengenai suatu perbuatan yang dianggapnya tidak salah atau bukan suatu kejahatan. Hal ini terjadi karena seorang anak yang melihat seorang yang cukup umur/dewasa melakukan perbuatan tersebut. contohnya adalah membolos sekolah, pergi dari rumah tanpa sepengetahuan orangtua, dan berprilaku menentang orang tua.

2. Juvenile Deliquence merupakan suatu karakter seorang anak dimana anak tersebut berbuat suatu kenakalan yang dianggap kenakalan tersebut sama dengan perbuatan suatu pelanggaran atau kejahatan yang diperbuat oleh orang dewasa seperti contohnya anak-anak smp melakukan tindakan pengeroyokan atau peelakuan verbal melalui media sosial yang mengakibatkan korbannya mengalami tekanan mental dan berujung dengan bunuh diri ${ }^{16}$.

Unsur-unsur penyebab timbulnya perbuatan kenakalan anak yang berlabihan sehingga dikatakan sebagai suatu kejahata dapat dilihat dari kehidupan lingkungan sekitar anak tersebut, bagaiaman ekonomi keluarga dalam situasi anak, dan hal penting lainnya yaitu psikologi dari anak tersebut ${ }^{17}$.

Hukum pidana menentukan mengenai pertanggungjawaban seseorang dalam tindakannya melakukan suatu tindak pidana dikarenakan seorang tersebut memiliki kesadaran dan juga mengerti bahwa tindakkan tersebut memang dilarang atau melanggar ketentuan aturan hukum yang berlaku. Ada beberapa unsur-unsur dalam tindak kejahatan atau pidana seperti telah adanya perbuatan manusia, tindakan yang dilakukan sesuai dengan ketentuan hukum, terdapatnya suatu kesalahan, pertanggungkawaban kepada pihak yang melakukan tindak pidana ${ }^{18}$.

Prilaku bullying/ kenakalan anak dapat dikategorikan dalam Juvenile Deliquency. Anakanak atau anak remaja dalam bahasa Inggris memiliki arti juvenile. Sedangkan jika mengacu mengenai suatu pelanggaran atau perbuatan kriminal dapat diartikan sebagai delinquency. Deliquency atau dalam tutur kata Indonesia delikuensi berarti

\footnotetext{
${ }^{16}$ Djamil, M. Nasir, Op.Cit, hlm.33.

${ }^{17}$ Abdul Hakim dan Tan Kamelo, Peranan Polri Dalam Penanggulangan Tindak Pidana Pencurian Oleh A. Jurnal Mercatoria Universitas Sumatera Utara, vol.6 no.2, edisi Desember 2013, http://ojs.uma.ac.id/index.php/mercatoria/article/view/638/538, diakses tanggal 28 April 2019.

${ }_{18}$ Djamil, M. Nasir, Op.Cit, hlm.34.
} 
tindak-tanduk yang melanggar asas dan kaidah hukum yang sedang berlaku secara ringan.

Seorang anak dapat dikategorikan delikuensi jika perbuatan anak tersebut berkonflik dengan kaidah hukum yang aktif di kalangan kelompok sosial dimana kehidupan antisosial dalam kehidupannya mengandung suatu unsur anti-normatif didalamnya ${ }^{19}$.

Ada beberpa perilaku anak yang menjurus terhadap perbuatan yang memiliki unsur juvernile delquence seperti yang dijelaskan oleh Alder seperti tindakan berkendara melebihi batas kecepatan dan menggangu kemanan dalam berlalulintas, lingkungan sosial yang ugal-ugalan yang mendorong seorang anak untuk bertingkahlaku arogan, urakan dan menggangu ketentraman sekitar, membolos disekolah, melakukan tindakan mengancam, mengintimidasi, mengeroyok yang dilakukan oleh anak dan lain-lain ${ }^{20}$.

Dari penjelasan mengenai perbuatan yang mengandung unsurjuvenile deliquence diatas ada beberapa yang mencirikan tindakan praktek bullying yang sering terjadi seperti tindakan kriminalisasi anak yang meliputi mengancam, mengintimidasi, memeras, dan lain-lain, oleh karena itu, dimana tindakan bullying setiap anak yang menimbulkan tekanan fisik ataupun psikologis yang berujung dengan tekanan mental dan kehilangan nyawa dari para korban maka tindakan terebut masuk dalam tindakan pidana.

\subsubsection{Tindakan Hukum Terhadap Anak Pelaku Bullying}

Agar tidak adanya tindakan praktek bullying ini terjadi lagi maka harus adanya tindakan hukum dan penanggulangan terhadap kenakalan oleh anak-anak. Dari segi pemidanaan, anak yang melakukan tindakan bullying sampai berhadapan dengan hukum yang bersifat melanggar kaidah atau norma hukum dapat dikenakan pidana pokok berupa peringatan dari lembaga pembinaan anak, pidana yang bersyarat seperti memberikan pembinaan kepada anak-anak yang bermasalah agar memiliki sikap yang berbudi pekerti, melakukan pelayanan masyarakat atau adanya pengawasan dari pihak yang ditentukan oleh petugas yang berwenang, melakukan pelatihan kerja, dan alternatif terakhir yaitu dimasukkan ke dalam penjara anak. Hal ini ditentukan dalam aturan mengenai sistem peradilan anak pada Pasal 71 ayat (1) Undang-undang Nomor 11 Tahun 2012.

Peradilan yang diberlakukan terhadap anak yang melakukan tindakan kenakalan bullying ini prosesnya relative lebih ringkas dibandingkan dengan orang usia matang, dari segi prosedur penahanan, penyidikan, penuntutan, dan peradilannya. Selain itu selama proses peradilan pelaku bullying yang berstatus sebgai $\mathrm{ABH}$ diwajibkan untuk didampingi oleh orangtua/wali dari anak tersebut atau pihak-pihak yang memiliki kaitan dengan anak tersebut. Dalam menjalani proses persidangan anak ini memiliki proses yang jauh berbeda dari proses persidangan biasa, seperti contohnya dalam proses persidangan anak hakim tidak boleh mengenakan toga atau atribut yang mencerminkan seorang hakim.

${ }^{19}$ Ibid, hlm. 35.

${ }^{20}$ Eleanora, F. N, Op. Cit, 139. 


\subsubsection{Penanggulangan Terhadap Anak Pelaku Bullying}

Dengan adanya fenomena kenakalan anak atau praktek bullying yang sering terjadi sampai menyebabkan $\mathrm{ABH}$ maka perlu adanya tindakan penanggulangan untuk mengurangi kenakalan anak tersebut. Adapun upaya-upaya penanggulangan secara terpadu bersama-sama dalam menyikapi fenomena bullying atau kenakalan yang dilakukan oleh anak seperti yang dijelaskan oleh Kartini Kartono seperti tindakan preventif yang berfokus pada suatu pencegahan kenakalan anak seperti meninggkatkan kesejahteraan di lingkungan keluarga anak, memperbaiki lingkungan kehidupannya, menyediakan tempat hiburan rekreasi anak yang aman, dan lain-lain. Selain mencegah adapula usaha tindakan dalam memberikan efek jera atau hukuman terhadap anak dengan tindakan represif berupa memberikan hukuman terhadap anak sesuai dengan tindakannya secara adil dan dapat merubah sikap dan hati nuraninya agar memiliki budiperti yang lebih baik kelak saat tumbuh dewasa. Tindakan represif digunakan untuk anak yang telah masuk dalam proses peradilan dengan memberikan hukuman sesuai dengan perbuatan yang dilakukan oleh anak pelaku tindakan bullying. Upaya terakhir dalam kasus kenakalan anak yaitu tidnakan kuratif dimana tindakan ini dilakukan untuk rehabiliasi atau penyembuhan baik secara fisik atau psikis dari korban maupun pelaku bullying21.

Dari uraian diatas dapat disimpulkan bahwa penanggulanan yang dapat dilakukan terhadap anak pelaku bullying dapat dilakukan dengan 3 tindakan yang pertama tindakan preventif dimana tindakan ini lebih ke bentuk kepedulian untuk melihat situasi kondisi lingkunan anak. Selanjutnya tindakan represif atau tindakan penghukuman dimana anak yang melakukan kesalahan harus tetap diberikan hukuman atas perbuatan yang dilakukannya. Terakhir adalah tindakan kuratif yaitu tindakan pemusnahan penyebab dari kenakalan, bisa dengan cara melakukan perubahan lingkungan pergaulanan anak, mencarikan orang tua asuh, atau dengan pelatihan remaja dengan berdasarkan kedisiplinan.

\section{Kesimpulan}

Berdasarkan pada hasil kajian hukum dan pembahasan mengenai tindakan bullying dilihat dari aturan hukum yang ada dapat disimpulkan sebagai berikut:

Bullying merupakan suatu bentuk tekananyang dilakukan oleh anak dibawah umur terhadap teman-temannya yang sesama umur, dimana tindakan tersebut dilakukan baik itu secara fisik, verbal, atau psikologis. Praktek tindakan bullying yang menimpa seorang anak merupakan salah satu contoh dari kenakalan yang bersifat berlebihan dan juga suatu tindakan yang merenggut hak-hak atas berkembangnya seorang anak. Dengan adanya kaidah yang mengklasifikasikan tentang kedaulatan hak anak seperti dalam Undang-undang Dasar Negara Republik Indonesia Tahun 1945 Pasal 28b ayat (2) dan Undang-undang Nomor 35 Tahun 2014 tentang Perlindungan anak, maka jika kedaulatan hak seorang anak dilanggar maka itu merupakan suatu perbuatanyang bertentangan dengan hukum, termasuk salah satunya yaitu tindakan bullying. jadi tindakan bullying ini tidak termasuk tindak kenakalan anak biasa melainkan suatu tindak pidana.

${ }^{21}$ Djamil, M. Nasir, Op.Cit, hlm.34. 
Bullying masuk dalam kategori anak yang berkonfilk dengan hukum. Oleh karena itutindakan hukum yang dapat ditajuhkan kepada anak pelakubullying dapat dikenakan pidana pokok dalam aturan sistem peradilan anak berupa memberikan peringatan, pidana bersyarat, memberikan pelatihan kerja terhadap anak, pembinaan, dan hukuman penjara anak.

\section{Daftar Pustaka}

\section{$\underline{\text { Buku }}$}

Djamil, M. Nasir , 2013, Anak Bukan Untuk Dihukum, Sinar Grafika, Jakarta.

Ishaaq, 2017, Metode Penelitian Hukum Penulisan Skripsi, Tesis, Serta Desertasi, Alfabeta, Bandung.

\section{Jurnal}

Abdul Hakim dan Tan Kamelo, Peranan Polri Dalam Penanggulangan Tindak Pidana Pencurian Oleh Anak. Jurnal Mercatoria Universitas Sumatera Utara, vol.6 no.2, edisi Desember 2013, http://ojs.uma.ac.id/index.php/mercatoria/article/view/638/538, diakses tanggal 28 April 2019.

Eleanora, F. N, Kajian Yuridis Penerapan Sanksi Tindakan Terhadap Anak Yang Melakukan Tindak Pidana Menurut Undang-Undang No. 3 Tahun 1997 Tentang Pengadilan Anak. ADIL: Jurnal Hukum, vol.6 no. 2, edisi Desember 2015, $\quad$ http://www.academicjournal.yarsi.ac.id/index.php/JurnalADIL/article/view/819/475, diakses tanggal 28 April 2019.

Juita, S. R., Sihotang, A. P., \& Ariyono, A, Cyber Bullying Pada Anak Dalam Perspektif Politik Hukum Pidana: Kajian Teoretis Tentang Undang-Undang No. 11 Tahun 2008 Tentang Informasi Dan Transaksi Elektronik Sebagaimana Diubah Dengan Undang-Undang No. 19 Tahun 2016. Jurnal Dinamika Sosial Budaya, vol.8 no.2 edisi Desember http://journals.usm.ac.id/index.php/humani/article/view/1380, diakses tanggal 28 juni 2019.

Putra, K. V. A., Swardhana, G. M., \& Purwani, S. P. M. Penanggulangan Tindak Pidana Pengeroyokan Yang Dilakukan Oleh Anak Di Bawah Umur Di Wilayah Hukumpolresta Denpasar. Jurnal Fakultas Hukum Universitas Udayana, vol.7 no.1 edisi Januari 2018, https://ojs.unud.ac.id/index.php/kerthawicara/article/view/37714, diakses tanggal 26 April 2019.

Regina Putri Pratiwi, Hubungan Perilaku Bullying Dengan Kemampuan Interkasi Sosial Siswa Kelas III SDN Minomartani 6 Sleman. Jurnal Fakultas Imu Pendidikan Universitas Negeri Yogyakarta, vol.5 no.2 2016, http://journal.student.uny.ac.id/ojs/index.php/pgsd/article/view/415, diakses tanggal 26 April 2019.

Handayani, T, Perlindungan Dan Penegakan Hukum Terhadap Kasus Kekerasan Seksual Pada Anak. Jurnal Hukum Mimbar Justitia, vol.2 no.2 edisi Desamber 
2016, https://jurnal.unsur.ac.id/jmj/article/view/33/25, diakses tanggal 28 Juni 2019.

Nurdina, M. A., \& Tri Andrisman, F. Penegakan Hukum Pidana Terhadap Pelaku Tindakan Penindasan Atau Bullying Di Sekolah Dasar. Jurnal Poenale, vol. 6. no.2 edisi Maret 2018, http://jurnal.fh.unila.ac.id/index.php/pidana/article/view/1189/1006, diakese tanggal 28 Juni 2019.

Wiharsa, I Made, Diversi Tinak Pidana Narkotika Dalam Sistem Peradilan Pidana Anak. Jurnal Magister Hukum Udayana (Udayana Master Law Journal), vol.6 no.1 edisi Mei 2017, https://ojs.unud.ac.id/index.php/jmhu/article/view/26369, diakses tanggal 27 April 2019.

Winna A. A. Senandi dan Tom A. S. Reumi, Penanggulangan Deliquency (Kenakalan Anak dan Remaja), Dampak dan Penanganannya. Jurnal Fakultas Hukum Universitas Cendrawasih, vol.2 no.3 edisi nopember 2018, http://ejournal.uncen.ac.id/index.php/JP/article/ view/659, diakses tanggal 26 April 2019.

\section{Internet}

Arbi Sumandoyo, Polisi Tahan 7 Siswa Pelaku Bullying di SMA Don Bosco, https://www.merdeka.com/jakarta/polisi-tahan-7-siswa-pelaku-bullyingsma-don-bosco.html. Diakses pada tanggal 29 April 2019.

Andry Haryanto, Pelajar Pelaku Bullying Dikeluarkan Dari Sekolah, https://www.liputan6.com/news/read/3026316/pelajar-pelaku-bullying-dithamrin-city-dikeluarkan-dari-sekolah. Diakses pada tanggal 29 April 2019.

\section{Peraturan Perundang-undangan:}

Undang-Undang Dasar Negara Republik Indonesia Tahun 1945.

Undang-undang Nomor 3 Tahun 1997 Tentang Pengadilan Anak.

Undang-Undang Nomor 39 Tahun 1999 tentang Hak Asasi Manusia.

Undang-undang Nomor 11 Tahun 2012 Tentang Sistem Peradilan Pidana Anak.

Undang-undang nomor 35 Tahun 2014 Tentang perubahan atas Undang-undang Nomor 23 tahun 2002 Tentang Perlindungan anak.

Keputusan Presiden No. 36 Tahun 1990 tentang Pengesahan Konvensi Hak-Hak Anak. 